\title{
An Analysis of Syntactical Errors and MistakesFound in English Oral Presentation
}

\author{
Shally Amna \\ University of Putra Indonesia YPTK Padang, Indonesia. \\ shallyamna@upiyptlk.ac.id
}

\begin{abstract}
When students present oral English presentation, syntactical errors and mistakes will frequently tend to occur. This research is aimed at analysing the syntactical errors and mistakes found in English oral presentation. The sample taken is the students of Economic Faculty in 2018/2019 who were taking Communication and Presentation in English course. This research used qualitative and descriptive methods. The instruments used are the transcription of the oral presentation and interview. The data are analysed descriptively by using the category of syntactical errors and mistakes by Browns (2007) and Corder (1967). The analysis showed that the most common errors and mistakes are inincomplete unit of a sentence, confusion of using part of speech and wrong use of 'to be'. The result of the study can be used by the lecturer to see the students' lack of English competency and specify the teaching materials.
\end{abstract}

Keywords: Syntactical Errors and Mistakes, Oral Presentation

\section{Introduction}

Along with the opening of the free market era in Indonesia, foreign and multinational companies are growing and developing rapidly in Indonesia. Many of them prefer to use foreign workers because their English skills are better than local people. The presence of foreign workers will certainly threaten employment opportunities for Indonesians. Therefore we must prepare Indonesian graduates to be proficient in English. Definitely the level of language proficiency that is desired by is not just a speaking skill in basic everyday conversation, but also the ability to express sentences in English in business activities, one of which is the presentation of products or services to be offered to consumers or clients with formal and standard English.

The use of formal English in accordance with grammatical rules in business presentations is an important thing that must be understood by business people especially students majoring in Management in the Faculty of Economics. Some studies were concerned with troubles that the students may have during oral presentation such as nervousness.[1-2]. One of the main problems aroused was the anxiety or fear in speaking. Researchers have consistently revealed that anxiety can impede ELF students' language production [3]. For this reason, the faculty has designed an English Communication and Presentation course for students to have excellent English communication and presentation skills. Therefore, after teaching theory and providing exercises, researchers are interested in examining English grammatical errors that still appear in the student's oral presentation.

The purpose of this study was to analyse the syntactical errors and mistakes made by students majoring in management of the faculty of economics in the use of English sentences when conducting business presentations in class. In addition, this study also aims to determine the percentage of grammatical errors made by each student in delivering English sentences orally without text (without reading) and classifying the errors based on their type.

In general, someone will convey his ideas in oral form. Every idea or idea that someone has in practice will be poured into sentence form. Arranging sentences starts with stringing words, and forming units of subject, predicate, object, complement, and description. Furthermore, a series of sentences that form a unity of meaning will become a paragraph and more broadly become a discourse. A good sentence must be arranged based on the correct structure, the expression of ideas in a good, precise, clear meaning and polite. Mistakes and irregularities in sentence 
form can be caused by various things including the author's lack of knowledge of the elements or sentence patterns. This study specifically investigated syntactical errors and mistakes during the students oral presentation.

The results of this study are expected to be useful not only for students as research subjects but for English language lecturers, especially in the faculty of economics, as a form of evaluation of the English learning process and the course of Communication and English Presentation. It is hoped that this research will be able to contribute to the improvement of the curriculum, especially in semester learning plans for each subject under the group of English studies.

researchers and teachers that includes collecting language samples of students, recognizing errors contained in the sample, describing the errors, classifying them based on the causes which has been hypothesized, and evaluates its seriousness. The incompatibility of presenting in English were caused by many problems such as language barrier and ignorance. Most students could present the issues briefly. There are some errors and mistakes frequently happen and seemed to be ignored by the students. However, these errors and mistakes during the presentation did make a disturbance for the audiences especially with native English. The flaws could alleviate quality of the presentation as a whole and leave it with bad mark.

Although having lots of theories and preparation before the presentation, students still struggled with error and mistakes. The term of errors and mistake was firstly discussed by James (1998, p. 1) who gave a somewhat preliminary definition of an error as "an unsuccessful bit of language" [4]. Brown (2007:1) states that when learning a new language, someone need to fight the boundaries of their first language and try to reach the new language, new culture, new way of thinking, feel and emotion. He also states that learning a new language is a process with mistakes [5]. No one can avoid making mistakes, but one should learn from the mistakes and takes the lesson to avoid making the same mistakes in the other time.

There are several kinds of mistakes in learning English, namely syntactical, clausal, and phrasal mistakes [6]. In language learning, there are two terms used namely mistakes and errors. Brown (2007) argues that there are two ways people make mistakes in language learning. First, the students know the system but fail to apply, and the second one is the incompetence of the students to perform the language. He explains that mistakes should be differentiate from errors [4]. An errors shows a capacity of learning process, while mistake is a failure in performing a language. Corder (1967) explains that errors in language learning happens when the speaker break the language rules (breaches of code) which cause when the speaker has already mastered one language with different rules when learning another language [7].

The dichotomy between errors and mistakes has been broadly discussed among applied linguistics scholars. Bottley (2015) has elaborated many experts' opinion and come to the idea that errors are usually defined as systematic deviations from the rules of a target language [8]. They may occur because a learner does not know a rule, such as Subject-Verb Agreement in English. Mistakes, on the other hand, are seen as unintentional, accidental slips resulting from simple laziness or forgetting.

A wide range of previous researches have been found relating this present study. And to consider the main focus of the this reseach, there are only a few studies selected to be reviewed. Those are ones dealt with investigating errors or mistakes produced by EFL learners to see the analysis and the feedback given. Ngangbam (2016) who has done a research which titled, "An analysis of Syntactic Errors committed by students of English Language Class." has found that the most problems committed in his study were due to mother tongue interference, misuse sentence fragment, overuse and lack of grammatical knowledge. [9]. Pramadya (2018) in his research found that the most syntactical errors and mistakes found are in tense, passive-active sentences and subject and verb agreement [10]. Futhermore, Hafiz et.al. (2018) revealed on their study that most common syntactic errors made by the learners are in sentence structure; subject-verb agreement, tense and auxiliary verbs. Many of their students were categorized as slow learners so non-seriousness and less concentration of learners result errors and mistakes in their writing [11]For the sake of brevity, we can say that, errors are not commonly made by native speakers since these only happen because of lack of knowledge. However, mistakes are commonly happen to EFL learners. In fact, in Indonesian language or in mother tongue the mistakes can sometimes occur such as: We suppose to say: Kenapa kamu terlambat? This interrogative sentence contains with complete unit of a sentences. But we say : Napa terlambat? Because sometimes we ignore correct pattern in informal situation.

\section{Research Method}

The research is a qualitative descriptive research. According to Arikunto (2013) descriptive research is a research to investigate the situation, condition, activity and events which results in descriptive report [12]. The participant of the research were 80 students in management department of Economic faculty, Andalas University in the academic year of 2018/2019 who took English Communication and Presentation subject. Data is taken from Oral English Presentation from Students who were grouped to

Lesson Journal: Languange, Applied Linguistics, and Education Journal Vol .3 Issue 1 (2021) 9-12 
present a certain topic related to Current Economic Issues. The students did the presentation for about 20 minutes for each group by using power point as their media of presentation.

The students' oral presentation were recorded and transcript during the presentation. In analysing the data, this research used several instruments and techniques of analysis. These are errors and mistakes sheets and interview sheets. The method of data analysis used is the referential method [13]. The data then were analysed in the category of grammatical errors and mistakes. Each error and mistake is elaborated and the common reasons are outlined descriptively.

\section{Result and Discussion}

Syntactical errors and mistakes have occurred many times in students' oral presentation. These may occur in grammatical or lexical aspects. Despite having years of learning English grammar, the students kept making errors and mistakes. Those are elaborated as follow:

a. Failing to use proper verb tense

Student sentence: 'I make my homework', he supposed to say 'I do my homework.' This is categorized as an error.

b. Subject and Verb agreement

Student sentence: 'We presents the data.' The students make a mistake by adding $-s$ to the word present.

c. Gender agreement

Student sentence: 'Tony drunk a lot wine. She was out of control last night.' The students make a mistake by saying she instead of $h e$.

d. Unspecific Questions

- 'How is the payment system?'

- 'Next is question?'

Both of these questions are bias due to the lack of the object in the interrogative sentence. The students supposed to add some objects or another information like 'How is the payment system of the allowance?'

e. Incomplete unit of a sentence.

- Missing Object: 'We hope you will enjoy here'. Just like the previous mistake, thestudent forgot to add an object after the verb enjoy.

Another mistake is like, 'The first X, I'll explain...' the correction is the first step is...

- Missing Noun: The first is me

- Missing Subject or Pronoun:

- In this picture $\mathrm{X}$ will shoot the film scene, too.
- Before X start our presentation

- Next is X presentation

- Missing Verb

- how to make this movie trending topic in the because the movie is so natural and high quality

f. Confusion of figures of speech.

- In the process of create this film

- to exhibition of the movie

- ....to presentation...

- We will presentation...

- We promotion the movie

- Most of these are written in noun while they supposed to write in verb. For instance: to exhibition, should be to exhibit.

- Confusion of People and Things

- Opening session to attract the tourism.

- The word Tourism should be changed into tourist.

- Confusion of Adjective and verb

- The singer will be more entertain the audience

g. Problems with word order

- 'Famous artist International'

The students are fail to join the adjective and noun properly. It should be written as 'afamous international artist/actress'

h. Confusion passive-active sentence

- 'Everything cannot predict'

The sentence should be written in passive and it will be like ' Everything cannot be predicted.'

i. The wrong use of "to be"

- 'I will ask is when the promotion will be..'

- 'You are is one of them we will invite.'

- 'There is 2 problems..'

- 'There is 100 invitations, is to our production,

- Most of the mistakes occur because they didn't consider the subject of the sentence.

j. Confusion of Ordinal and Cardinal Number

- 'The three type.'

- 'The type 2 is the Deluxe Package..'

- 'Price for type 1 is....

- 'These two is my colleges..'

k. Preposition Problems

- 'I will explain with you..'

- 'We want for give you..'

1. Tenses Problem

- 'About the previous movie, how do you promote it?'

Lesson Journal: Languange, Applied Linguistics, and Education Journal Vol .3 Issue 1 (2021) 9-12 
- 'We give you the brochure, right?'

The tense problem is categorized as errors since most students could not fix the sentencesinto the correct one.

\section{Conclusion}

The research has been done to analyse students' syntactical errors and mistakes. The mistakes are the most frequent cause which decrease the students' performances in oral English presentation. The most frequent mistakes occurred are the incomplete unit of a sentence and the confusion in the figure of speech. Essentially, English teachers may support their students to be confidence to practice their English without having too much worry of their grammar problems as a good start. However, in the level of university, this cannot be tolerated anymore, when they have to be ready to find a job and compete with English language. Based on this research, there are several notes of errors and mistakes classification which often occur during the oral presentation. The lecturers can use the data to improve their lesson plan by adding exercises related to errors and mistakes in syntax so the same cases with infrequently happen again.

\section{References}

[1] Chuang, Y. Y. (2011). The effectiveness of implemented oral activities and instructions in the college EF classroom. Journal of National Formosa University, 30.

[2] Abu El Enein, A.H. (2011). Difficulties encountering English majors in giving academic oral presentations during class at Al-Aqsa University. PhD Thesis, Gaza, Islamic University of Gaza.

[3] Al-Nouh, A. N.; Taqi, H. \& Abdul-Kareem, M.M. (2014). EFL primary school teachers' attitudes, knowledge and skills in alternative assessment. International Education Studies, 7(5), 68-84. http://dx.doi.org/10.5539/ies.v7n5p68

[4] James, C. (1998). Errors in Language Learning and Use: Exploring Error Analysis. Harlow, Essex: Addison-Wesley Longman.

[5] Brown, Douglas.H. (2007). Principles of Language Learning and Teaching, Fifth Edition. Pearson Education, Inc.

[6] Ramlan, M. (1987). Sintaksis Ilmu Bahasa Indonesia. Yogyakarta: Karyono.

[7] Corder, S.P. (1967).The significance of learners' errors. IRAL, $5,161-170$.

[8] Botley, S.P. (2015). Errors Versus Mistakes : A False Dichotomy. Malaysian Journal of ELT Research, Vol. 11(1), pp. 81-94.

[9] Ngangbam, Hembati (2016). An Analysis of Syntactic Errors Committed by Students of English Language Class in the Written Composition of Mutah University: A Case Study. European Journal of English Language, Linguistics and Literature. Vol. 3. No.1 ISSN 2059-2027.

[10] Pramadya, H. (2018). Analisis Kesalahan Gramatika Dalam Presentasi Bisnis Berbahasa Inggris. Journal Sekretaris dan Administrasi Bisnis. Vol II (1) 2018. Pg. 84 -94 .

[11] Fafiz, M.S. et al. (2018). An Analysis of Syntactic Errors in English Writing: A Case Study of Jazan University Preparatory Year Students. Journal of Education and Practice. Vol. 9. No. 11, 2018. ISSN 2222-1735.

[12] Arikunto, Suharsimi. (2013). Prosedur Penelitian: Suatu Pendekatan Praktik. Jakarta: Penerbit Rineka Cipta.

[13] Sudaryanto, D. P. (2015). Metode dan aneka teknik analisis Bahasa [Method and technique of language study]. Yogyakarta: Sanata Dharma University Press. 